NBER WORKING PAPER SERIES

\title{
CURRENCY BASKETS AND REAL EFFECTIVE \\ EXCHANGE RATES
}

\author{
William H. Branson \\ Louka T. Katseli \\ Working Paper No. 666
}
NATIONAL BUREAU OF ECONOMIC RESEARCH 1050 Massachusetts Avenue
Cambridge MA 02.138

April 1981

\footnotetext{
Thanks go to Ramon Fspinosa and Cynthia Arfken for research assistance. The research reported here is part of the NBER's research program in International studies. Any opinions expressed are those of the authors and not those of the National Bureau of Economic Research.
} 
NBER Working Paper $\$ 666$

April 1981

Currency Baskets and Real Effective Exchange Rates

ABSTRACT

With the major currencies continuously moving (if not floating freely) against each other, a country that does not choose to float must decide what to peg to. If it pegs to the SDR it floats against all currencies. Thus in the system begun in the early 1970s the very concept of a fixed exchange rate is unclear. In this situation many countries have chosen to peg their currencies to a basket, or a weighted average of other currencies.

The analysis of this paper is focused on fluctuations in real exchange rates. We first show that pegging to a currency basket is the same as holding constant a real effective exchange rate that uses a specific set of weights depending on a chosen policy target. We also show the weights that correspond to particular targets for stabilization policy.

Next we discuss several problems involved in choosing and computing optimal weights or the equivalent real effective rate. It is shown that the index formula itself aggregates countries that are in a currency area, so that monetary authorities should use weights based on trade with countries rather than on currency denomination of trade.

Finally, we report on an initial empirical investigation of pegging practices in Greece, Portugal, and Spain. These are all countries that have moved to basket pegs, with geographically diversifled trade. We present initial estimates of the implicit weights in their baskets, and find that all three countries experienced real appreciation relative to the basket during the 1970s.

William H. Branson Woodrow Wilson School

Princeton University

Princeton, N.J. 08544

(609) 452-4828
Louka T. Katse1i

Economic Growth Center

Yale University

Box 1987, Yale Station

New Haven, CT 08540

(203) $436-8414$ 
W.H. Branson

L.T. Katseli

$3 / 28 / 81$

Currency Baskets and Real Effective Exchange Rates

\section{Introduction and Summary.}

With the major currencies continuously moving (if not floating freely) against each other, a country that does not choose to float must decide what to peg to. If it pegs its currency to one of the major currencies, it floats against the others. If it pegs to the SDR it floats against all currencies. Thus in the system begun in the early 1970 s the very concept of a fixed exchange rate is unclear.

In this situation many countries have chosen to peg their currencies to a basket, or a welghted average of other currencies. This trend was noted by Arthur Lewis in his Per Jacobssen lecture at the IMF:

"It is now the conventional wisdom that the currencies of the developed countries should float, but the currencies of the less-developed (LDCs) should not; that is to say that each LDC should choose a more developed country (MDC) as a partner -- or the SDR -- and tie itself in a flxed relationship." (Lewis, 1977, p. 33).

Since the SDR weights are not particularly relevant for any single country, many countries compose their own basket.

Generalized floating (or dirty floating) raises problems of measurement. What is meant by "the" exchange rate in a floating, multiple-currency world? The answer that has appeared in the literature is an "effective" exchange rate, which is generally some.trade-weighted Index of changes in the home currency price of vartous foreign currencies. 
The IMF now publishes data on effective exchange rates. These are based on the IMF's multiple exchange rate model (MERM), described by Artus and Rhomberg (1973). It will be shown in this paper that this is only one of a possible number of definitions for an "effective" exchange rate that depends on the implicit choice of a target for exchange rate policy.

In an earlier paper [Branson-Katseli (B-K) (1981)] presented at a conference in Stockholm in 1978, we derived weights for currency baskets that would eliminate the effects of other countries' nominal exchange rate fluctuations on various home-country policy targets. There we considered the problem of choosing a currency basket in the presence of third-country exchange-rate fluctuations, holding prices constant. In this paper we extend that discussion in several ways.

First, in section 2, we focus our analysis on fluctuations in real exchange rates and show that pegging to a currency basket is the same as holding constant a real effective exchange rate that uses a specific set of weights depending on the chosen policy target. We also show that the optimal weights of the earlier paper can be used for currency baskets defined across real exchange rate fluctuations. The underlying model of trade prices and quantities is similar to the one in $B-K$ (1981) and is summarized in Appendix 1.

The model of section 2 differs from others in the recent 1iterature In two respects. First, a partial equilibrium approach is adopted as opposed to the general equilibrium model of Flanders and Helpman (1979). This affects the exact composition, but not the general form of the weights. 
Second, we derive weights that insulate policy targets from third-country real exchange-rate fluctuations. The alternative in the literature is to adopt a variance-minimizing approach for a portfollo or a vector of targets. Examples are Flanders and Helpman (1979), de Macedo(1979), and Lipschitz and Sundararajan (1980). They derive weights which differ from ours in form, being functions of the variance-covarfance structure of movements In real exchange rates.

In sections 3 and 4 we discuss several problems involved in choosing and computing optimal weights or the equivalent real effective rate. In section 3 it is shown that the index formula itself aggregates countries that are in a currency area, so that monetary authorities should use weights based on trade with countries rather than on currency denomination of trade. In section 4 optimal weights are combined with a crawling peg against the basket.

Finally, in section 5 we report on an inftial empirical investigation of pegging practices, in Greece, Portugal, and Spain. These are all countries that have moved to basket pegs, with geographically diversified trade. We present initial estimates of the implicit weights in their baskets, and find that all three countriss experienced real appreciation relative to the basket during the 1970s. 
2. Real Effective Exchange Rates and Optimum Welghting Schemes

The objective of this section is to extend our previous work [Branson-Katsel1 (1981)] on the choice of welghts for currency baskets and to develop further the theoretical framework for analyzing the construction of and role of real effective exchange rates in the exercise of exchange-rate policy.

It is easiest to begin with a definition of a real effective exchange rate, and then go on to show how different currency basket weights define alternative real effective rates. Table 1 gives a complete listing of the symbols that will be used throughout the paper. 
Table 1: Symbols and Definitions

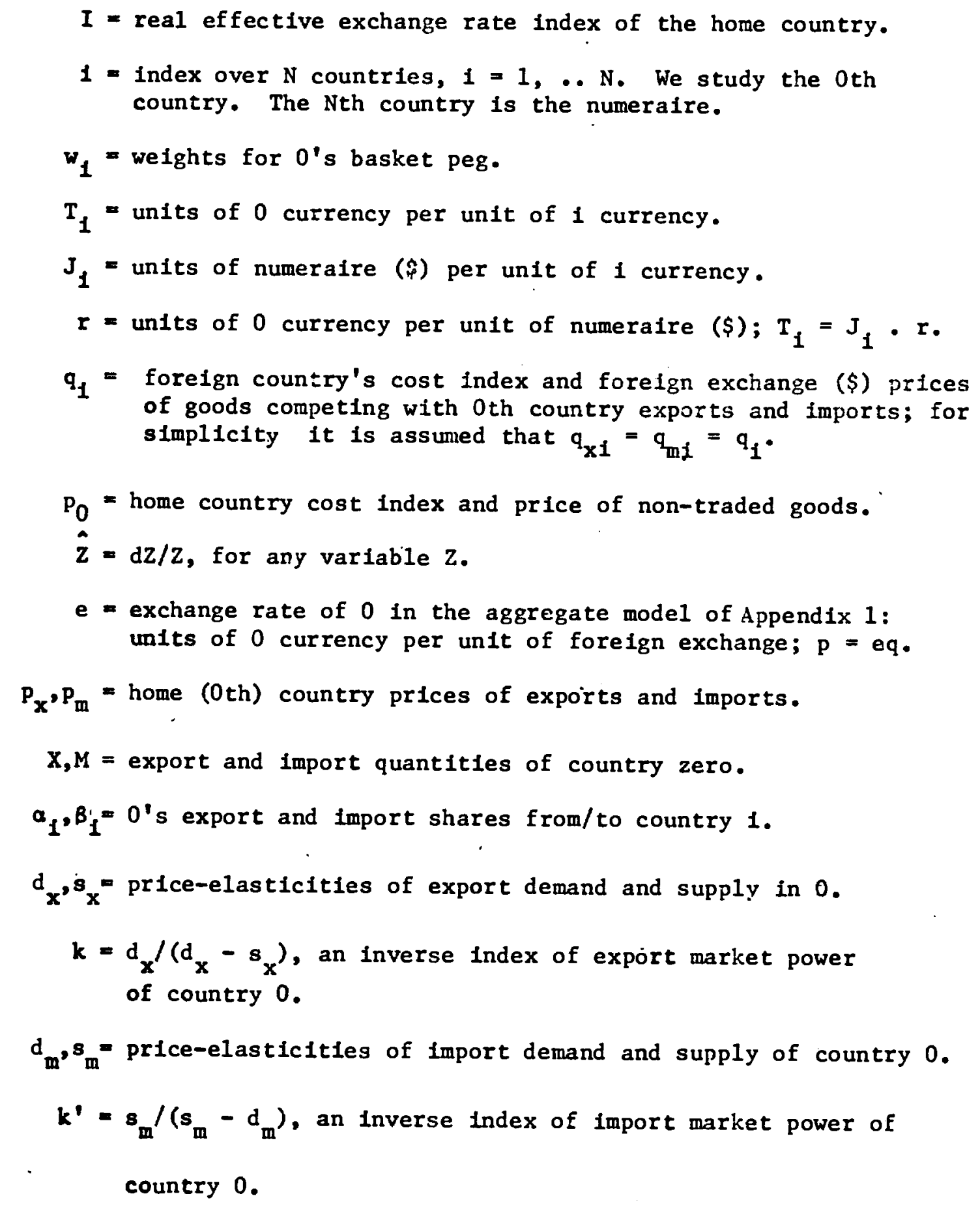


Movements in a real effective rate index for the home country (country zero) are given by

(1) $\quad \hat{I}=\sum_{1}^{N} w_{1}\left(\hat{T}_{1}+\hat{q}_{1}-\hat{p}_{0}\right) ; \sum w_{1}=1$,

where the weights $w_{1}$ remain to be chosen. Noting that the bilateral exchange rate of the home country 0 against country $i\left(T_{1}\right)$ can be decomposed into the home country price of an arbitrarily chosen numeraire, $r$, and the numeraire price of the currency $1, J_{1}$, the numeraire can be factored out of the index in (I) as follows. Substitute $J_{1} r$ for $T_{1}$, and add and subtract $\hat{q}_{N}$ to obtain

$$
\hat{I}=\sum_{N} w_{i}\left(\hat{J}_{i}+\hat{r}+\hat{q}_{i}-\hat{q}_{N}+\hat{q}_{N}-\hat{p}_{0}\right)
$$

Since the weights sum to unity, the real exchange rate vis-a-vis the numeraire can be factored out to give

(2) $\quad \hat{I}=\left(\hat{r}+\hat{q}_{N}-\hat{p}_{0}\right)+\sum_{N} \omega_{1}\left(\hat{J}_{1}+\hat{q}_{1}-\hat{q}_{N}\right)$.

In equation (2) the first term represents the home-country real exchange rate against the numeraire, and the second term is the weighted sum of the numeraire's real rate against all other countries.

Now consider a policy rule that moves the nominal exchange rate against the numeraire $r$ to hold I constant:

(3) $\quad \hat{r}+\hat{q}_{N}-\hat{p}_{0}=\sum_{N} w_{1}\left(\hat{J}_{1}+\hat{q}_{I}-\hat{q}_{N}\right)$, or $\hat{I}=0$. 
This policy rule both stabilizes the effective real exchange rate I defined by $w_{i}$ and pegs the real rate in terms of the numeraire to the currency basket across all $\mathrm{N}$ currencies (including the numeraire) defined by the same weights $w_{1}$. Thus if the home-country real exchange rate vis-a-vis the numeraire is held equal to the basket real exchange rate defined by a given set of weights $w_{i}$, the real effective exchange rate defined by those weights is held constant.

The weights $w_{i}$ in equation (3) can be chosen to insulate one of a number of targets from movements in third-country exchange rates vis-a-vis the numeraire. Examples of such targets from B-K (1981) are (a) the terms of trade $p_{x} / p_{m},(b)$ the balance of payments $p_{x} X-p_{m} M$, and (c) the price ratio of traded and non-traded goods. In principle, these optimal basket weights may be calculated for a variety of policy targets. Flanders and Helpman (1979) and Lipschitz and Sundararajan (1980), for example, derive optimal basket weights for some of these as well as other policy targets. The policy targets can, in turn, be expressed as combinations of trade prices and quantities as shown in B-K (1981). 'In Appendix 1 changes In trade prices and quantities are expressed as functions of movements in (a) the home country's real exchange rate against the numeraire, $\hat{r}+\hat{q}_{N}-\hat{p}_{0}$, and (b) the numeraire's real exchange rate against third countries, $\hat{j}_{1}+\hat{q}_{i}+\hat{q}_{\hat{N}}$. These can be combined to give an expression for movements In the chosen target variable which can in turn be set equal to zero to solve for the weighting scheme $w_{1}$ that insulates that particular combination 
of trade prices and quantities from movements in third-country real exchange rates.

\section{Balance of Trade Weights.}

The balance of trade is given by $B T=p_{x} X-p_{m}$. If we index $p_{x}$ and $p_{m}$ to unity initially, so $p_{x}=p_{m}=1$, differentiation of this expression for the trade balance yields

$$
\text { (4) } \quad d B T=\left(\hat{p}_{x}+\hat{x}\right) x-\left(\hat{p}_{m}+\hat{M}\right) M \text {, }
$$

Here $X$ and $M$ are the initial levels of trade. Substitution from equations

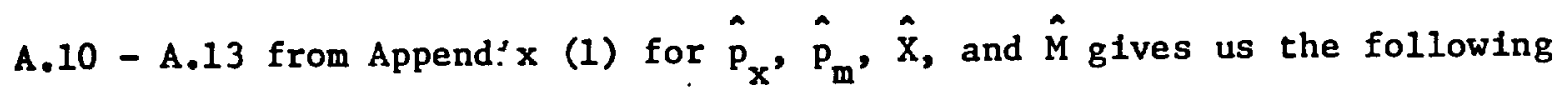
expression for the change in the trade balance, in home currency terms:

$$
\begin{aligned}
d B T= & (X-M) \hat{p}_{0} \\
& +\left[X k\left(1+s_{x}\right)-M k \cdot\left(1+d_{m}\right)\right]\left(\hat{r}+\hat{q}_{N}-\hat{p}_{0}\right) \\
& +X k\left(1+s_{x}\right) \sum_{N}^{\sum \alpha_{1}}\left(\hat{J}_{i}+\hat{q}_{i}-\hat{q}_{N}\right) \\
& -M^{\prime}\left(1+d_{m}\right) \underset{N}{\sum \beta_{i}}\left(\hat{J}_{i}+\hat{q}_{1}-\hat{q}_{N}\right) .
\end{aligned}
$$

The first term is the effect of home price changes with a given initial balance; the second term gives the effect of changes in the real exchange rate against the numeraire; the term in brackets is the Marshall-Lerner condition. The last two terms give the effects of changes in third-country real exchange rates on export and import values, respectively. 
To obtain the weights for the currency basket that would stabilize the trade balance, we set $d B T=0$ in (5), and solve for the real effective exchange rate Index:

$$
\hat{r}+\hat{q}_{N}-\hat{p}_{0}=\frac{X-M}{X k\left(1+s_{x}\right)-M k^{\prime}\left(1+d_{m}\right)} \hat{p}_{0}-\sum_{N} w_{i}\left(\hat{J}_{1}+\hat{q}_{1}-\hat{q}_{N}\right),
$$

with weights $w_{i}$ given by

$$
w_{1}=\frac{X k\left(1+s_{x}\right) a_{1}-M k^{\prime}\left(1+d_{m}\right) B_{1}}{X k\left(1+s_{x}\right)-1 k^{\prime}\left(1+d_{m}\right)}
$$

These are the same as the balance-of-trade weights (37) in B-K (1981), and are essentially the same as the IMF's effective MERM weights. If Initially $X=M$, the result of (6) for the real exchange rate against the numeraire $\mathrm{N}$ is given by

$$
\hat{\mathbf{r}}+\hat{q}_{N}-\hat{p}_{0}=-\sum_{N}\left(\hat{J}_{1}+\hat{q}_{i}-\hat{q}_{N}\right)
$$

The nominal rate should be moved to make movements in the real rate equal to movement in the weighted average of third-country real rates, with weights given by (7). These define a currency basket stabilizing the balance of trade; they also define an effective rate I with reference to stabilizing the trade balance. 


\section{Terms-of-trade welghts.}

We could derive welghts insulating the terms of trade $\mathrm{P}_{x} / \mathrm{P}_{\mathrm{m}}$ from third-country real exchange rates from equations (A.10) and (A.12) In Append 1x 1. However, given the balance-of trade welghts in (7), we can proceed more directly. Assume $X=M$ initlally, and eliminate quantity effects from the balance-of-trade welghts by assuming $s_{x}=d_{m}=0$. Then those welghts become the terms-of-trade weights

(8) $w_{i}=\frac{k \alpha_{i}-k^{\prime} B_{1}}{k-k}$.

These are the same as (28) In $B-K$ (1981), and they define a currency basket or effective rate that would stabilize the terms of trade. As noted in $B-K$ (1981), In the small-country case where $k=k^{\prime}=1$, exchange-rate policy cannot influence the terms of trade; weights (18) are relevant only when $k \neq \dot{k}^{\prime}$.

Weights stabilizing the relative price of traded goods.

Equation (7) gives weights for a currency basket almed at stabilizing the trade balance. These are essentially defined as weights for "the" effective exchange rate in the IMF 11terature. See, for example, Artus-Rhomberg (1973). On the other hand, as early as 1976, Stanley Black derlved weights aimed at stabllizing the relative price of traded vs nontraded goods. These define an alternative effective exchange rate orlented toward relative prices. 
In B-K (1981), the Black weights were shown to be the small-country case of a more general scheme, as we now see.

Movements in the price of traded goods can be written as

$$
\hat{p}_{T}=z_{x} \hat{p}_{x}+z_{m} \hat{p}_{m}
$$

where $z_{x}$ and $z_{m}$ are welghts of exports and imports in total trade in value terms, and $z_{x}+z_{m}=1$. Substitution from equations $(A .10)$ and (A.12) in Append $1 x$ for $\hat{p}_{x}$ and $\hat{p}_{m}$ ylelds

$$
\begin{aligned}
\hat{p}_{T}=\hat{p}_{0} & +\left(z_{x} k+z_{m} \hat{r}^{\prime}\right)\left(\hat{r}+\hat{q}_{N}-\hat{p}_{0}\right) \\
& +z_{x} k \sum \alpha_{N}\left(\hat{J}_{1}+\hat{q}_{1}-\hat{q}_{N}\right) \\
& +z k_{N}^{\prime} \sum \beta_{1}\left(\hat{J}_{1}+\hat{q}_{1}-\hat{q}_{N}\right) .
\end{aligned}
$$

Movements in the price of non-traded goods are given by domestic cost cpnditions, represented by $\hat{\mathrm{p}}_{0}$. To hold $\mathrm{p}_{\mathrm{T}} / \mathrm{p}_{0}$ constant, we thus have the solution

$$
\text { (11) } \hat{r}+\hat{q}_{N}-\hat{p}_{0}=-\sum_{N} w_{1}\left(\hat{J}_{1}+\hat{q}_{1}-\hat{q}_{N}\right) \text {, }
$$

with the weights $w_{1}$ given by

$$
\text { (12) } \quad w_{1}=\frac{z_{x} k a_{1}+z_{m} k^{\prime} B_{1}}{z_{x} k+z_{m} k^{\prime}} \text {. }
$$

These are the same as B-K (1981), equation (32), and they provide an effective exchange rate or currency basket stabilizing the relative price 
of traded vs non-traded goods as third-country real exchange rates fluctuate. In the small-country case, these simplify to total trade weights:

$$
w_{1}=z_{x_{1}^{\alpha}}+z_{m_{i}^{\beta}}^{\beta}
$$

These are Black's (1976) preferred weights.

The weighting expressions in equations (7), (8), and (12) give alternative weights for currency baskets, or definitions of real effective exchange rates, for alternative targets of exchange-rate policy. The Important points here are that, (a) as in our earlier work [B-K $(1980,1981)]$, each weighting system defines an effective exhcnage :ate that corresponds to a chosen target, but (b) the weights here, as opposed to the model in B-K $(1980,1980)$, are used to define an index across real exchange rates. Even though the analysis is a straightforward extension of the earlier model it is an important extension in that it permits us to consider the cases of PPP and of independent variations in prices and exchange rates as extreme cases of one general framework. Next we turn to some comments on the application of weighting schemes in the exercise of exchange-rate policy. 
3. Issues in calculating optimal weights.

The weighting schemes of section 2 use trade weights $\alpha_{1}$ and $\beta_{1}$, and they are aggregated to the point where each country has a single import-competing price disturbance $\hat{q}_{1}$ and all countries have the same elasticity of demand $d_{x}$ for one export good. Two kinds of questions have been raised in considering how to apply any of these schemes.

One is whether trade weights or currency weights are appropriate. The second is how to disaggregate, in general across commodities. Two examples of the disaggregation question are whether to use trade or current account weights, and how to adjust for the commodity composition of exports across, e.g., agriculture, mining, manufacturing. In this section we will consider these two kinds of questions in turn.

Trade shares vs currency shares.

Up to this point, we have noted the small-country special case in passing. But we have left for separate discussion a problem that generally appears as one of two seemingly different questions. These are as follows: (1) How should trade weights be modified if trade is denominated in a world currency? For example, Zambia's copper exports are stated in sterling as determined on the London metal exchange. (2) Should we not use shares of currency denomination in the $\alpha_{1}$ and $\beta_{1}$ weights, rather than direction of trade? The first question was first raised at a seminar at Columbia University, Apr11 19, 1978. The second was raised in Lipschitz (1979) and again in discussions at the Finance Ministry in New Delhi, and the Monetary Authorfty of Singapore, January 9 and 28, 1980. Here we show that these questions are essentially the same, that they are really the question of the smallness of this 
countries, and that they are already answered in the formulation of the real exchange rate in the weighting schemes of section 2 .

Consider first the question of using currency area weights instead of trade welghts in the calculations. Suppose a subset $H$ of the third countries denominate their trade with the home (zero) country in dollars, as an example. Then it seems intuitively plausible to argue that those countries should be included In a "dollar area," and that their welghts should be combined with that of the U.S. In calculations. This is not quite correct, though.

The true importance of the fact (if, indeed, it is a fact) that a country h prices its trade in dollars is the implicit assumption that country h's prices move with U.S. prices, adjusted for the movements in h's dollar exchange rate, $J_{h}$. This is the assumption that $h$ is a small country relative to the United States. In this case the real exchange rate of $h$ vis-a-vis the U.S. Is constant, and the term $\hat{J}_{h}+\hat{q}_{h}-\hat{q}_{N}$ in the weighting calculations is zero.

The implications of this for the use of the weighting schemes can be seen by concentrating again on the example of the export price index for country zero from Appendix 1:

$$
\hat{p}_{x 0}=\hat{p}_{0}+k\left(\hat{r}+\hat{q}_{N}-\hat{p}_{0}\right)+k \sum \alpha_{1}\left(\hat{J}_{1}+\hat{q}_{1}-\hat{q}_{N}\right)
$$

Suppose the U.S. dollar is chosen as numeraire, so $\mathrm{N}$ is the U.S. Conoider first a case in which all other country's prices are Independent 
of the U.S. Then a $q_{N}$ impulse will raise $p_{x 0}$ by

$$
\hat{p}_{x 0}=k \hat{q}_{N}+k \sum_{1}^{N-1} \alpha_{i}\left(-\hat{q}_{N}\right)=k \alpha_{N} \hat{q}_{N} .
$$

The summation in the third term of (13) runs across all $\mathrm{N}$ countries. Thus the $\hat{q}_{\mathrm{N}}$ impulse is entered with a weight of unity in the term giving the real exchange rate of the home country against the numeraire, but it is taken out

$$
\mathrm{N}-1
$$

with a weight $\sum \alpha_{1}$ by the term giving movement in third-country real exchange rates. Thus the weighting scheme itself gives a lone $\hat{q}_{N}$ impulse a weight of $a_{N} \cdot$

Now consider a case in which some subset of $\mathrm{H}$ countries $(1, \ldots, h, \ldots, H)$ have prices that move with the dollar, so that for each of these the real exchange rate vis-a-vis the dollar is constant. This is the case in which the $h$ countries are small relative to the U.S., and one would wish to integrate them into a dollar currency area. Now the effect of a $q_{N}$ impulse on $P_{x 0}$ is given by

$$
\hat{p}_{x 0}=k \hat{q}_{N}+k \sum_{H+1}^{N-1} \alpha_{1}\left(-\hat{q}_{N}\right)=k\left(\alpha_{N}+{\left.\stackrel{\sum}{L} \alpha_{1}\right) \hat{q}_{N}}_{1}^{H}\right.
$$

Thus the aggregation of countries that are truly in a currency area In the sense that their real exchange rates are constant vis-a-vis each 
other is accomplished by the weighting index. If countries price their trade in the same currency, but their prices move independently, they will not and should not be aggregated. But if their prices move together, they automatically will be.

The problem of a country which is selling a comodity priced in a numeraire on the world market is essentially the same. If copper trades at one world price, then all the relevant $q_{1}$ for a copper exporter will move together, and be aggregated by the indexes into one world market. At this level, the appropriate aggregation is again automatically achieved by the index. The real problem for a commodity exporter will come with commodity disaggregation within the importing countries. This takes us to the disaggregation question.

\section{Levels of disaggregation.}

While the indexes of equations (A.10) - (A.13) will perform the aggregation of the world market for a single-commodity exporter, they do not take into account the probability that in each country 1 , the demand price for the commodity moves somewhat independently of the average import-competing price. This example raises one question of disaggregation. The formulas In equations (A.10) - (A.13), and the subsequent weighting schemes, treat each country 1 as importing a single good with demand elasticity $d_{x}$. To Implement the weighting schemes Ideally, one would want to use for $q_{1}$ the internal demand prices in country 1 for the particular exports and Imports of the home country zero, and apply to them the appropriate disaggregated elasticity and share parameters. Thus for a country exporting only copper, one would ideally use movements in copper prices in the various 1 countries, combined with estimates of elasticities relevant 
for copper, and the exporter's trade shares. This would then give the correct index for that country's $\hat{\mathrm{p}}_{\mathbf{X}}$, etc., and the proper calculation of welghts.

Another mafor example of the disaggregation issue is the choice between current account and trade shares for $\alpha_{1}$ and $\beta_{1}$. The effective weighting schemes of the IMF [see, for example Artus and Rhomberg (1973)], and the portfollo welghts of Kourt and de Macedo (1978) and de Macedo (1979) use current account shares.

In general, we would expect the services components of the current account to have different elasticities than the trade component. For example, if migrant workers determine the value of their remittances in terms of foreign exchange, $k$ is effectively unity. If they $f i x$ the value in terms of their home currency, $k$ is effectively zero. Thus ideally, the shares should be current account shares, and the elasticities should be averages of the trade and services components. Consistency would suggest not using trade elasticities with current account shares.

The broad point here is that the formulas of section 2 are highly aggregated, with elasticities implicltly given as weighted averages of the relevant trade and services components. One can obtain a first aggregate approximation for the welghting schemes by using trade or current account shares $\alpha_{1}$ and $\beta_{1}$ and the corresponding average elasticities. But more precise calculation would require appropriate disaggregation of both shares and elasticities. 
4. Adjustment of the real exchange rate and choice of optimal weights.

The optimal welghting schemes of section 2 give alternative sets of weights for real exchange rates which have the following property: if the home country real exchange rate vis-a-vis the numeraire follows the path of the real basket rate, effects of third-country fluctuations in real rates w11l not affect the chosen target. Thus if the nominal rate $r$ is manipulated to maintain

$$
\hat{r}+\hat{q}_{N}-\dot{p}_{0}=-\sum_{N} w_{i}\left(\hat{J}_{1}+\hat{q}_{1}-\hat{q}_{N}\right),
$$

with the appropriately-chosen welghts $w_{1}$, the target is insulated from movements in real rates $\left(\hat{J}_{1}+\hat{q}_{i}-\hat{q}_{N}\right)$.

In the case of the balance-of-trade weights, this movement in the real rate will maintain trade or current account balance, depending on whether the $w_{1}$ include trade or current account weights. On the other hand, the terms-of-trade weights and the weights stabilizing the ratio of prices of traded and non-traded goods $\left(\mathrm{p}_{\mathrm{T}} / \mathrm{p}_{0}\right)$ will not in general meet a balance-of-payments target. If those weights are chosen, there w11l still remain the need for adjustment of the real rate relative to the basket to hold the balance of payments near its target. One way to achleve this adjustment would be to adopt a crawling basket peg such as

$$
\text { (14) } \hat{r}+\hat{q}_{N}-\hat{p}_{0}=-\sum_{N} w_{1}\left(\hat{J}_{1}+\hat{q}_{1}-\hat{q}_{N}\right)+F(B, R),
$$

where $B$ is the balance on current account or overall payments, and $R$ is reserves. This is the real-rate equivalent of the basket crawl formula (4) in B-K (1981). 
The adjustment function $F$ in equation (14) gives the speed at which the home-country real rate is adjusted relative to the basket real rate. This is also the speed of adjustment of the real effective rate defined by $w_{1}$. The arguments of $F(\cdot)$ are the external-balance indicators used to adjust the real effective rate. Obvious choices for these indicators would include flows such as the current-account balance, or stocks such as reserves relative to a target level. These are represented by $B$ and $R$, respectively, in (14). The optimal weighting of these indicators is analyzed in Branson-de Macedo (1980).

Since adjustment of the real effective rate, perhaps using a craw1 formula, can be used to maintain payments balance, it would seem sensible not to choose the trade-balance weights for the currency basket. One can use, for example, the traded vs non-traded goods $\left(\mathrm{p}_{\mathrm{T}} / \mathrm{P}_{0}\right)$ weights to eliminate variance in that ratio, and combine. this with a basket crawl to maintain payments balance. This combination would, of course, give a non-zero trend in the $\mathrm{P}_{\mathrm{T}} / \mathrm{P}_{0}$ ratio as the real rate vs the numeraire moves relative to the basket, i.e., when $F(\cdot) \neq 0$. This would be the trend in $\mathrm{P}_{\mathrm{T}} / \mathrm{P}_{0}$ needed to meet the external balance target chosen for the $\mathrm{F}$ adjustment function. However the choice of weights (12) for $\mathrm{P}_{\mathrm{T}} / \mathrm{P}_{0}$ would reduce the variance around that trend.

To summarize, adjustment of the real effective rate can be used to maintain external balance. This means that the weights for the currency basket can be oriented toward a target other than the trade balance, namely toward one of the relative-price targets. Use of one of those 
welghting schemes will then stabllize the chosen target around the trend dictated by the necessary adjustment of the real effective rate. 


\section{Application to exchange-rate experience in Southern Europe.}

Three countries in Southern Europe, Greece, Portugal, and Spain, have experimented with versions of basket pegs since exchange rates began to float in the early 1970s. In this section we briefly examine their experience, to see whether their choice of weights roughly conforms to the analysis above. We begin with a brief description of their experience. Next we discuss choice of targets for these countries, and finally we examine the evidence.

\section{Experience since 1971.}

Following the breakdown of the Bretton-Woods system of fixed parities, Greece, Portugal, and Spain each sought to pursue a more flexible exchange rate policy. Given the fact that the major currencies exhibited substantial fluctuations vis-a-vis each other, pegging the exchange rate to any single one of them meant substantial and continuous realignments vis-a-vis the others. Since all three countries have geographically diversified trade (see Table 2 below), this implied that each would experience analogous movements in the home-currency price of traded commodities if not of the terms of trade.

As early as the third quarter of 1971, Spain and Portugal abandoned the dollar currency area and followed the Deutsche mark (DM) in its upward trend against the dollar. This continued until the middle of 1975 when both countries, hit by rising prices and appreciating effective real exchange rates, started devaluing in nominal terms vis-a-vis both hard currencies. The escudo's devaluation against the dollar has continued 
since; the devaluation against the DM halted around the end of 1979. The Spanish authorities, probably sensitive to the inflationary consequences of further nominal devaluations against as major a trading partner as Germany, reversed that trend at the third quarter of 1977 and attempted to stabilize the rate around 36 Pesetas/DM. This lasted approximately unt1l the end of 1979.

Greece followed the dollar in 1 ts downward movement vis-a-vis the other hard currencies for a much longer perlod than elther Spain or Portugal. The rate was held at $30 \mathrm{drachma} /$ dollar until the middle of 1975 when a basket peg was adopted and the drachma started devaluing vis-a-vis the basket. It is only towards the end of the decade, with rapid Inflation of Import prices and the CPI, that the rapid depreciation vis-a-vis the European currencles was slowed. Th1s policy shift was also prompted by increased trade prospects with the European Community (EC) In light of the Imminent entry into the EC, and the expected movement towards harmonization of monetary and exchange rate policles.

The experience of the three countries during the 1970's can be thus subdivided into three roughly comparable periods. In the first period, mid-1971 to mid-1975, Spain and Portugal maintained rough parities vis-a-vis the Deutsche mark and appreclated substantially vis-a-vis the dollar; in the case of Greece the opposite held true. In the second perIod which lasted to 1977 III in the case of Spain, and until the end of 1979 in the other two countries, all three countries experienced substantial effective nominal devaluations vis-a-vis all major trading partners. 
Since that time, monetary authorities have attempted to maintain rough parities with the European currencies.

\section{Choice of targets for the currency basket.}

Currency baskets aimed at stabilizing three different policy targets were discussed in section 2 above. The targets are the trade balance, the terms of trade, and the ratio of the price of traded goods to non-traded goods $\mathrm{P}_{\mathrm{T}} / \mathrm{P}_{\mathrm{N}}$. Which target would be most appropriate for Greece, Portugal, and Spain?

In section 4 , we argued that the effective real exchange rate can be varied to meet a balance of trade target. This implies movement of the home-currency real rate against the numeraire relative to the basket real rate, as illustrated in equation ( 14 ). In Table 3 below, we see that over the 1970 s the effective real rate appreciated, on average, in all three countries. In Table 4, we see that at least in the cases of Portugal and Spain, there is evidence that the effective real rate was responsive to an external balance target. Thus the choice of weights for the currency basket itself comes down to terms-ci-trade vs $P_{T} / P_{N}$ weights.

Exchange-rate policy can affect the terms of trade only in countries with non-zero net market power; $\left(k-k^{\prime}\right)$ in equation ( 8 ) must be non-zero. In Branson-Katseli (1980) we estimated indexes of market power on the export side and the import side for 101 countries. [See B-K (1980, pp. 62-67)]. Greece, Portugal, and Spain have relatively low values of the market power index, suggesting that the small-country assumption may be a good approximation in these cases. Thus the terms-of-trade welghts in equation ( ( ) are probably not approprlate. 
Q0-the other hand, there is evidence that in these countries exchangerate fluctuations do move $\mathrm{P}_{\mathrm{T}} / \mathrm{P}_{\mathrm{N}}$. Equations explaining quarterly movements In the consumer price index (CPI) for several countries were estimated in Katseli (1979). These include movements in export prices and import prices in dollars, and in the exchange rate as independent variables. The maximum estimated one-quarter elasticities of the CPI with respect to a traded-good price are: Greece, 0.26 (export price); Portugal, 0.37 (import price); Spain, 0.09 (import price). If these elasticities are close to the shares of traded goods in the CPI, the implicit elasticity of the ratio $\mathrm{P}_{\mathrm{T}} / \mathrm{P}_{\mathrm{N}}$ to changes in $\mathrm{P}_{\mathrm{T}}$ is close to unity. Given the smallness of these countries, this means that a given change in the exchange rate moves $\mathrm{p}_{\mathrm{T}} / \mathrm{p}_{\mathrm{N}}$ more than it moves the terms of trade.

Thus the scanty evidence that is available suggests that the $\mathrm{p}_{T} / \mathrm{p}_{\mathrm{N}}$ weights of equation (12) above would be most appropriate for Greece, Portu$\mathrm{gal}$, and Spain. If we assume that the three countries are small, which is consistent with the B-K (1980) calculations, these weights reduce to total trade weights, as noted at the end of section 2 .

\section{Evidence from Greece, Portugal, and Spain}

Table 2 shows the direction of trade for the three countries in the 1970s. In all three, the European Community (EC) is the largest trading partner,with a share around 50 percent. For Greece, Germany is the largest among the EC countries, the UK dominates for Portugal, and Germany and France come out about even in Spain. The U.S. share varies from 5 percent of Greek exports to 15 percent of Spanish Imports. The trade shares of Table 2 are the $\alpha_{1}$ and $B_{1}$ of the optimal weighting formulas. 


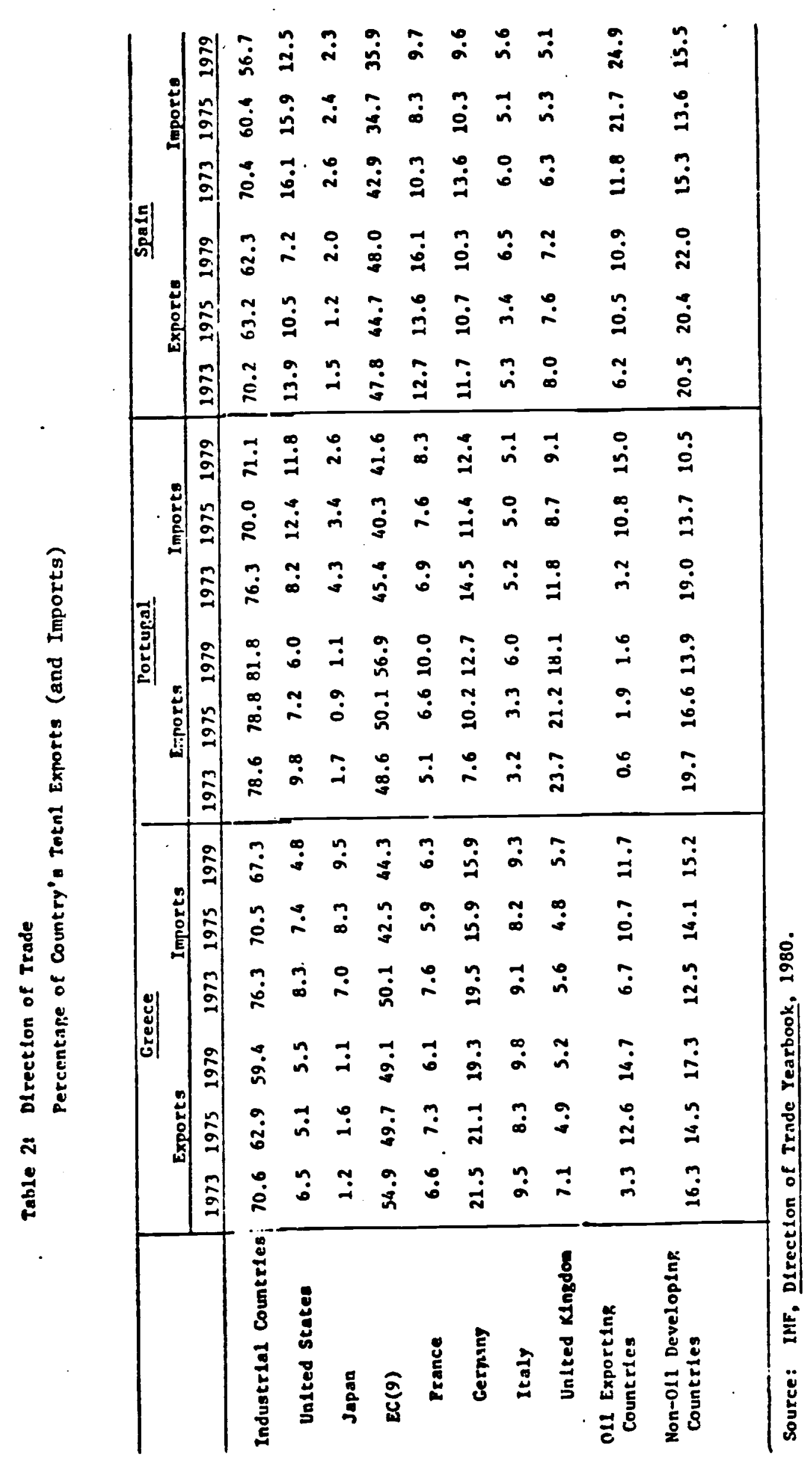


In Tables 3 and 4 we show the results of regression estimation of the welghts in equation (14) in section 4 above. The dependent vartable Is the quarterly percentage change in the country's real exchange rate relative to the U.S. dollar, $\hat{r}+\hat{q}_{u s}-\hat{p}_{0}$. The Independent variables are the percentage changes in the real exchange rates of the dollar agalnst the other major currencies, $\hat{J}_{i}+\hat{q}_{1}-\hat{q}_{u s}$ ( $1 \neq$ us); thus the signs of the coefficlents should be negative. The Implicit U.S. weight is one minus the absolute value of the sum of the estlmated weights for $1 \neq U S ; w_{\text {us }}=1-\Sigma w_{1}$. In Table 3 a constant term is included for the average movement of the real effective rate over the period; a negative coefficlent Indicates real appreciation. In Table 4 we add the level and rate of change of net forelgn assets, $F$ and $\hat{F}$, as indicators of external balance.

In general, the equations for Portugal and Spain seem reasonable; those for Greece are more difficult to interpret. This is probably due to the fact that Greece's currency basket was defined across nominal rather than real exchange rates. As has been shown in Katsel1 (1981), In the case where the basket is defined across nominal rates, the estimated weights are roughly the same as those of Table 3 but the explanatory power of the regression is markedly h1gher $\left(R^{2}-.28\right)$. In Table 3 , all the constants are negative, Indicating real appreclation relative to the basket. In Table 4, the level of net forelgn assets has a significant negative coefficlent for Spain; and both $F$ and $\hat{F}$ seem to play a role in Portugal.

The patterns of coefficlents giving currency weights permit us to draw several tentative but interesting conclusions: 
Table 3 : Movements of Real home-Currency Price of the Dollar Relative to Real Dollar

Price of Selected Currencies

(Quarterly Data $1970 I I-1930 I I I$

Percentage Change)

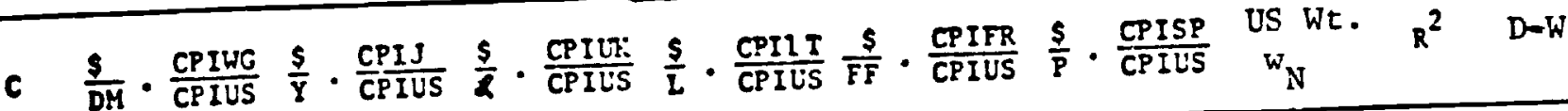

\section{GREECE}

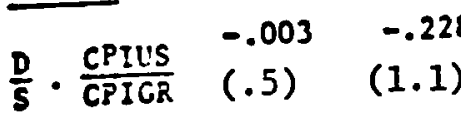

$\begin{array}{cc}-.002 & -.204 \\ (.4) & (1.0)\end{array}$

$\begin{array}{llll}.071 & -.049 & -.132 & .082 \\ (.5) & (.3) & (.4) & (.3)\end{array}$

$-\quad-.041$

$(.2)$
.105

(.4) $-\quad w_{N}=.580 \quad .0782 .2$

$-\quad w_{N}=.491 \quad .0732 .2$

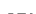

PORTUGAI

$\frac{E}{\text { CPIUS }} \frac{-.004}{\text { CPIPO }} \quad\left(\begin{array}{ll}-.652 \\ (3.2)\end{array}\right.$

.057

.045

$-.500$

.329
$(1.2)$

.007

$\mathrm{w}_{\mathrm{N}}=.279 \quad .3 \varepsilon 9 \quad 2.4$

$-.004 \quad-.634$

$-.051$

(1.6)

(1.2)

(.0)

$(.6) \quad(3.2)$

(.3)

.524

.348

$-.013$

$w_{N}=.228 \quad .3572 .3$

(1.8)

(1.3)

(.1)

\section{SPAIN}

\begin{tabular}{|c|c|c|c|c|c|c|c|c|c|c|}
\hline$\frac{8}{\delta} \cdot \frac{\text { CPIUS }}{C P I S P}$ & $\begin{array}{l}-.009 \\
(1.7)\end{array}$ & $\begin{array}{c}-.161 \\
(.9)\end{array}$ & $\begin{array}{l}-.053 \\
(.4)\end{array}$ & $\begin{array}{l}-.043 \\
(.3)\end{array}$ & $\begin{array}{l}-.441 \\
(1.8)\end{array}$ & $\begin{array}{l}-.024^{\circ} \\
(.1)\end{array}$ & - & $w_{N}=.278$ & .320 & 1.8 \\
\hline & $\begin{array}{l}-.009 \\
(1.8)\end{array}$ & $\begin{array}{c}-.179 \\
(1.1)\end{array}$ & - & $\begin{array}{l}-.049 \\
(.3)\end{array}$ & $\begin{array}{l}-.421 \\
(1.8)\end{array}$ & $\begin{array}{c}-.042 \\
(.2)\end{array}$ & - & $\begin{aligned}{ }^{w_{N}} & =.309 \\
& =\end{aligned}$ & .317 & 1.7 \\
\hline
\end{tabular}




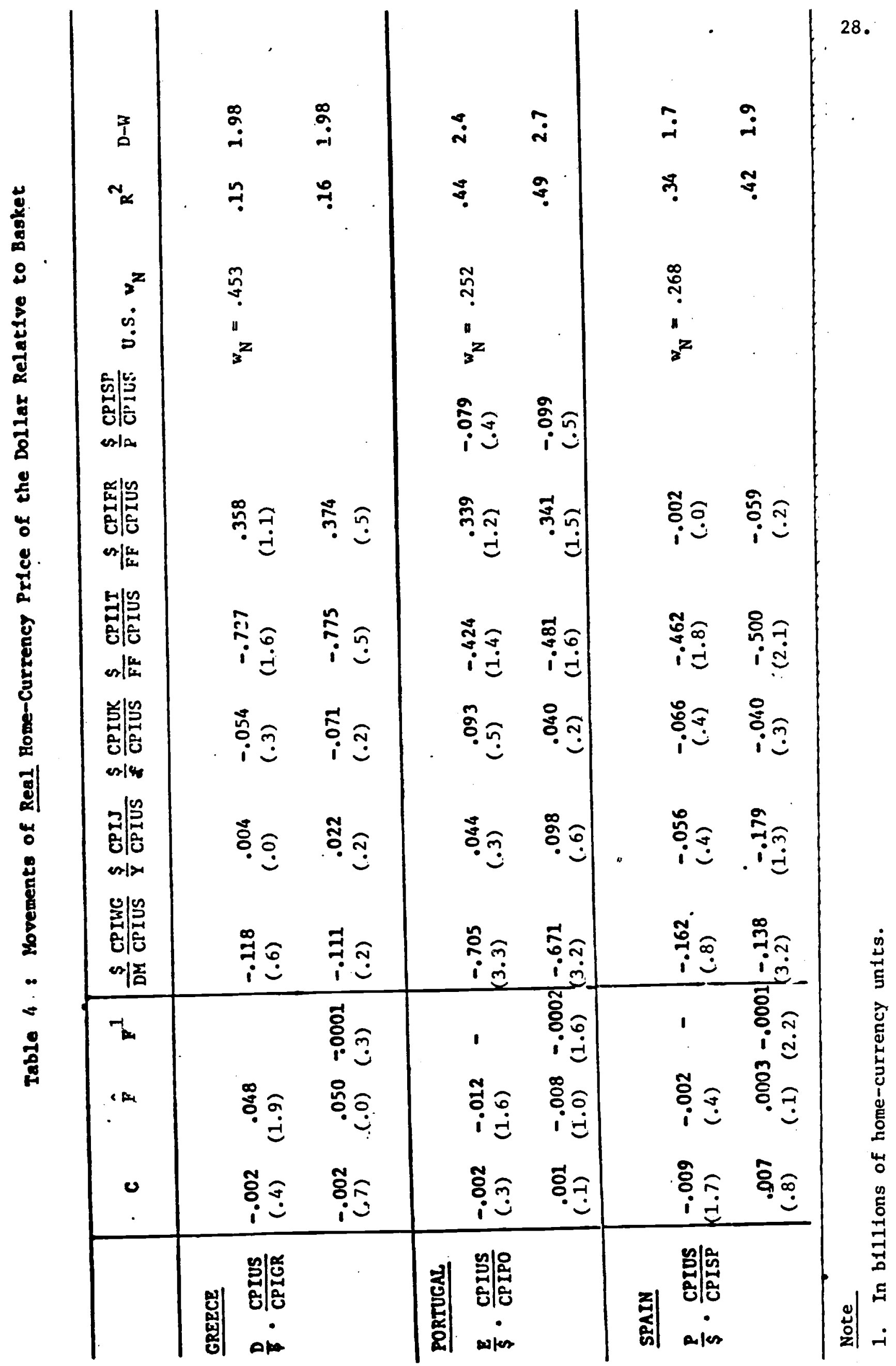


1. The estimated weights seem reasonable as a description of actual experience. They do not, however, correspond particularly closely even to our $\mathrm{P}_{\mathrm{T}} / \mathrm{P}_{\mathrm{N}}$ weights.

2. Over the whole period of the 1970s the weight of the dollar in the basket was markedly higher in the case of Greece than in either Portugal or Spain. This is hard to explain in terms of the Greek trade shares (Table 2) but can be understood in light of the inertia of the early period and preoccupation of the Greek authorities with balance of payments considerations.

3. The weight of the Deutsche mark is highest in the case of Portugal (.63). Here again the explanation is probably historical relationships and possibly a domestic inflation target. Maintaining a relatively stable rather than declining home-currency value of emigrant remittances might also be an important aspect of that choice.

4. In all three cases the share of the Italian lira is quite high. This probably reflects the preoccupation with competitive export positlons in third markets.

5. For all countries there was a nominal devaluation and real appreclation of their currency relative to the basket. The nominal devaluation was strongest in Portugal ( 8 percent on an annual basis) compared to Greece (approximately 4 percent) and Spain (less than one percent). [Katsel1 (1981)]. On the other hand, the real appreclation vis-a-vis the basket was strongest in the case of Spain (around 4 percent). 
6. Inclusion of the current account balance and the level of foreign assets as potential determinants of the adjustment vis-a-vis the basket seem to Improve both the Spanish and Portuguese results. This is especlally true for the stock of foreign assets, which proves to be an $1 \mathrm{~m}-$ portant determinant of the authorities' reaction to third-country exchange rate movements. Inclusion of these two variables seems to make little difference in the case of Greece.

These results suggest a general pattern: confronted with inflationary pressures in the mid 1970's from both domestic and foreign origins, the monetary authorities in all three countries attempted to safeguard their competitive position internationally through a process of nominal effective devaluations. These policies produced only a relatively small real effective exchange rate appreciation in the face of domestic inflation rates which at least in Spain and Portugal exceeded 20 percent by 1977.

Thus by the end of the 1970s these countries found themselves caught in the classic dilemma associated with exchange-rate policy, namely the conflict between balance-of-trade and domestic inflation targets. The econometric evidence, however sparse, seems to suggest that in small open economies the effects of exchange rate movements on the price ratio of traded to non-traded goods is higher than the effect on the terms of trade. The experience of these countries in the 1970 s and the switch in policies in the early 1980 s seem to substantiate that claim. 


\section{Appendix 1: A log-1inear trade model with real exchange rates.}

In this section a simple partial-equilibrium model is developed that provides the framework for the choice of weights for currency baskets or effective exchange rates. The model is essentially the same as that developed in Branson-Katsel1 (B-K, 1981), section IV. There Independence of movements in exchange-rates and price levels was implicitly assumed. Here the model is developed in terms of real exchange rates. It is a loglinear supply-and-demand model for exports and imports which includes the exchange rate as the translator between home and foreign prices. We begin with the simple two-country version, and then disaggregate to many countries and a numeraire.

Movements in aggregate trade prices and quantities.

Let us begin by concentrating on the export side. Export supply prices are assumed to be stated in home currency units $p_{x}$, while foreign import demand prices are given in foreign exchange units $q_{m}$. The supply function Is written as

$$
\text { (A.1) } \quad \ln p_{x}=\operatorname{lnp}+s_{x}^{-1} \operatorname{lnx} \text {. }
$$

Here $p$ is a shift parameter representing the domestic cost of production of exportables and $s_{x}$ is the price elasticity of export supply. We assume that $p$ is also the home-currency cost of production of import substitutes and non-tradeables. Equation (A.I) gives export supply $X$ as a function of the relative home-currency supply price $p_{x} / p$. The demand function giving the foreign currency price of exports is 


$$
\text { (A.2) } \quad \operatorname{lnq} x=\operatorname{lng}+d_{x}^{-1} \ln x \text {. }
$$

Here $q$ is a shift parameter representing the domestic cost of production of import-competing goods in the foreign country, and export demand depends on the relative price $q_{x} / q$. Again, we assume that $q$ is also the cost of production of exports in the foreign country. For the analysis in a case where domestic costs of production in the various sectors move differently, see $B-K$ (1981). The exchange rate e links $p_{x}$ and $q_{x}$ :

$$
\text { (A.3) } \quad p_{x}=e_{x}
$$

Substitution of $(A, 3)$ into $(A .2)$ for $q_{x}$ and total differentiation yields the expressions for percentage changes in export prices and quantities:

$$
\begin{aligned}
& \text { (A.4) } \hat{p}_{x}=k(\hat{e}+\hat{q})+(1-k) \hat{p}, \\
& \text { (A.5) } \hat{x}=k s_{x}(\hat{e}+\hat{q}-\hat{p}),
\end{aligned}
$$

where $k \equiv d_{x} /\left(d_{x}-s_{x}\right) ; 0<k \leq 1$. As noted in $B-K(1980,1981), k$ is an index of market power on the export side. In the small-country case $d_{x}+-\infty$ and $k+1$

The analogous model on the import side yields the equations for percentage changes in import prices and quantities:

$$
\begin{aligned}
& \text { (A.6) } \hat{p}_{m}=k^{\prime}(\hat{e}+\hat{q})+\left(1-k^{\prime}\right) \hat{p}, \\
& \text { (A.7) } \hat{M}=k^{\prime} d_{m}(\hat{e}+\hat{q}-\hat{p}),
\end{aligned}
$$

where $k^{\prime} \equiv s_{m} /\left(s_{m}-d_{m}\right) ; 0<k^{\prime} \leq 1$. Again, $k^{\prime}$ is an index of market power on the import side; for a small country where $s_{m} \rightarrow \infty, k^{\prime}+1$. 


\section{Disaggregation to many countries.}

To disaggregate the model, we consider a world of $N+1$ countries, $0, \ldots, N$. Country zero is the home country, whose exchange-rate policy we are analyzing. Country $\mathrm{N}$ is the numeralre, arbitrarlly chosen. Countries $j(-1, \ldots, j, \ldots, N-1)$ are the other (non-home, non-numeraire) countries in the system. The index 1 runs across all countries other than the home country, including the numeraire, thus $1=j, N$.

The home-country price index $p$ in equation (1) is now $P_{0}$. The importcompeting price in country 1 's demand function is $q_{m 1}$, and the exportsupply price of country 1 is $q_{1}$. The bilateral exchange rate of the home country 0 against country 1 is $T_{1}$, in units of currency zero per unit of currency 1. This can be decomposed into the home country price of the numeraire $r$, and the numeraire price of the currency $1, J_{1}$ :

$$
\text { (A.8) } \quad T_{1}=J_{1} r
$$

For exposition, we focus on disaggregation of movements in the export price $\hat{p}_{x 0}$; disaggregation of $\hat{x}_{0}, \hat{p}_{m 0}$, and $\hat{M}_{0}$ follow easily by analogy. With export weights given by $a_{i}, \hat{e}$ and $\hat{q}_{\text {in }}$ the $\hat{p}_{x}$ equation (A.4) are the aggregates

$$
\begin{aligned}
& \hat{e}=\sum_{1}^{N} \alpha_{1}\left(\hat{J}_{1}+\hat{r}\right) ; \\
& \hat{q}=\sum_{1}^{N} a_{i} \hat{q}_{1} .
\end{aligned}
$$

The disaggregated expression for $\hat{p}_{x 0}$ is now 
(A.9) $\hat{p}_{x 0}=\underset{N}{k \sum \alpha_{1}}\left(\hat{J}_{1}+\hat{r}\right)+k \underset{N}{k} \alpha_{1} \hat{q}_{1}+(1-k) \hat{p}_{0}$.

This is precisely the same as equation (24) in B-K (1981), with slight changes in notation. The analysis there proceeded in terms of nominal exchange rates. Here we wish to continue in terms of movements in real exchange rates.

First, let us add and subtract the change in the numeraire's importcompeting price $\hat{\dot{q}}_{N}$ in the second term of (A.9):

$$
\hat{p}_{x 0}=k \sum \alpha_{1}\left(\hat{J}_{1}+\hat{r}\right)+k \alpha_{N}\left(\hat{q}_{1}-\hat{q}_{N}+\hat{q}_{N}\right)+(1-k) \hat{p}_{0} .
$$

Now, remembering that $\sum \alpha_{1}=1$, we can re-group the terms on the righthand side into movements in real exchange rates:

$$
\hat{p}_{x 0}=\hat{p}_{0}+k\left(\hat{r}+\hat{q}_{N}-\hat{p}_{0}\right)+k \sum_{N} \alpha_{1}\left(\hat{J}_{1}+\hat{q}_{1}-\hat{q}_{N}\right)
$$

The first term on the RHS of (A.10) is the change in the domestic (zerocountry) export supply price due to changes in domestic cost conditions. The second term is the change in the home-country real exchange rate against the numeraire, using export prices. The third term sums the change in the numeraire's real exchange rate against all countries other than the home country, including the numeraire (country $N$ ), again using demand prices for exports of the zero country.

Several properties of $(A .10)$ for $\hat{\mathrm{p}}_{\mathrm{x} 0}$ are worth noting: 
1. If the home country is small, $k=1$ and $\hat{p}_{0}$ drops out of (A.10): $\hat{p}_{x 0}$ depends only on world prices and exchange rates.

2. An increase in the demand price $q_{j}$ in any one of the $j$ (nonnumeraire, non-home) countries clearly raise $p_{x 0}$ by $\hat{p}_{x 0}=k a_{j} \hat{q}_{j}$, proportional to $j$ 's share in home-country exports. The increase in $q_{j}$ also raises the numeraire's real exchange rate vis-a-vis $f$.

3. An increase in the demand price in the numeraire country alone raises $\mathrm{p}_{\mathrm{X} 0}$ by $\hat{\mathrm{p}}_{\mathrm{X} O}={ }^{\mathrm{a}} \alpha_{\mathrm{N}} \hat{q}_{\mathrm{N}}$, symmetrically to all the other countries. This results from the summation of the third term in (A.10) across all $1=1, \ldots, N$. Thus the formulation in (A.10) is completely symmetric across all non-home countries, with the numeralre chosen arbitrarily.

The disaggregation of the expressions for $\hat{X}, \vec{p}_{m}$ and $\hat{M}$, and their statement in terms of real exchange rates, follow analogously to the development from equation (A.4) for $\hat{\mathrm{P}}_{\mathrm{X}}$ to $(\mathrm{A.10})$ for $\hat{\mathrm{P}}_{\mathrm{X} O}$. The disaggregated version of (A.5) for the change in exports is

$$
\hat{x}_{0}=k s_{x}\left[\left(\hat{r}+\hat{q}_{N}-\hat{p}_{0}\right)+\sum_{N} a_{1}\left(\hat{J}_{1}+\hat{q}_{1}-\hat{q}_{N}\right)\right]
$$

On the import side, $\hat{e}$ and $\hat{q}_{x}$ in equations (A.6) and (A.7) disaggregate into

$$
\begin{aligned}
& \hat{e}=\sum_{1}^{N}\left(\hat{J}_{1}+\hat{r}_{1}\right) \text {, and } \\
& \hat{q}_{x}=\sum_{1}^{N} \hat{\beta}_{1} \hat{q}_{1}
\end{aligned}
$$


where $B_{1}$ are import weights, and $\Sigma B_{1}=1$. The disaggregated versions of (A.6) and (A.7) for $\hat{P}_{\mathrm{m} 0}$ and $\hat{M}_{0}$ are then given by

(A.12) $\quad \hat{p}_{m 0}=\hat{p}_{0}+k^{\prime}\left(\hat{r}+\hat{q}_{N}-\hat{p}_{0}\right)+k_{N}^{\prime} \sum \beta_{1}\left(\hat{J}_{1}+\hat{q}_{1}-\hat{q}_{N}\right)$,

(A.13) $\quad \hat{M}_{0}=k^{\prime} d_{m}\left[\left(\hat{r}+\hat{q}_{N}-\hat{p}_{0}\right)+\Sigma B_{i}\left(\hat{J}_{i}+\hat{q}_{1}-\hat{q}_{N}\right)\right]$.

In (A.12) and (A.13), the term $\left(\hat{r}+\hat{q}_{N}-\hat{p}_{0}\right)$ is the change in the home country's real exchange rate against the numeraire, and the term $\left(\hat{J}_{1}+\hat{q}_{1}-\hat{q}_{N}\right)$ is the real exchange rate of the numeraire against country 1 (including the numeraire), using the prices relevant for country zero's imports.

Equations (A.10) - (A.13) give the expressions for changes in export and Import prices and quantities in terms of movements in home prices and real exchange rates. 


\section{References}

Artus, J.R. and Rhomberg, R.K., A multilateral exchange rate model, IMF Staff Papers Vol. 20, No. 4 (1973), pp. 591-611.

Black, S.W., Exchange Rate Polfcles for Less Developed Countries in a World of Floating Rates, Princeton Essays on International Finance 119, (Princeton: International Finance Section, 1976).

Branson, W.H. and Katseli-Papaefstratiou, L.T., Income Instability, terms of trade, and the cholce of exchange-rate regime, Journal of Development Economics. Vol. 7, No. 1 (1980), pp. 49-69. , and - Exchange-rate pollcy in developing countries, In The World Economic Order: Past and Prospects, eds. S. Grassman and E. Lundberg (London: Macmillan, 1981), pp. $391-419$. , and de Macedo, J.B., The OptImal Welghting of Indicators for a Crawling Peg, National Bureau of Economic Research Working Paper No. 527, August, 1980.

Flanders, J.M. and Helpman, E., An optimal exchange rate peg in a world of. general floating, The Review of Economic Studies, Vol. XLVI, No. 3 (1979), pp. 533-542.

Katseli-Papaefstratiou, L.T., Transmisston of External Price Disturbances in Sma11 Open Econoniles (New York: Garland Press, 1979). Katseli, L.T., Macroeconomic Adjustment and Exchange-rate Policy in Middle-income Countries: Greece, Portugal, and Spain in the 1970s, Yale Economic Growth Center Discussion Paper No. 374, April 1981. 
Kour1, P.J.K and de Macedo, J.B., Exchange rates and the international adjustment process, Brook1ngs Papers on Economic Act1v1ty 1: 1978, Pp. $111-150$.

Lew18, W.A., The Less developed countries and stable exchange rates, in The International Monetary System In Operat1on (Wash1ngton: IMF, 1977).

Lipschltz, L., Exchange rate pollcy for a small developing country, and the selection of an approprlate standard, IMF, Staff Papers, Vol. 26, No. 3 (1979), pp. 423-449. , and Sundararajan, V., The optimal basket In a world of generallzed floating, IMF Staff Papers, Vol. 27, No. 1 (1980) pp. 80-100. de Macedo, J.B., Portfollo Diversification Across Currencles, Yale Economlc Growth Center, D1scussion Paper No. 321, September 1979. 